Contents lists available at Journal Redwhitepress
Journal of Educational and Learning Studies
ISSN: 2655-2760 (Print) ISSN: 2655-2779 (Electronic)
Journal homepage: http://journal.redwhitepress.com/index.php/jles

\title{
Assertive behaviour difference among domestic violence victims
}

\author{
Annisa Dwi Astuti, Alizamar Alizamar, Afdal Afdal \\ Universitas Negeri Padang
}

\begin{tabular}{l} 
Article Info \\
Article history: \\
Received Jun $13^{\text {th }}, 2019$ \\
Revised Aug $19^{\text {th }}, 2019$ \\
Accepted Sept $9^{\text {th }}, 2019$ \\
\hline
\end{tabular}

\section{Keyword:}

Assertive Behaviour Domestic Violance Victims

Education

\begin{abstract}
In 2017, the number of cases related to violence against women increased by $400 \%$ from the previous year. This research, therefore, aims to analyze behavior difference among domestic violence victims using a quantitative descriptive method. Data were obtained from 64 victims using a Likert scale, while the descriptive techniques and T-Test analysis were used to examine the data obtained. The results showed that the assertive behavior of women victims of domestic violence without elementary education was lower compared to those with junior, high, and college education.
\end{abstract}

(C) 2019 The Authors. Published by Redwhitepress.

This is an open access article under the CC BY-NC-SA license (https://creativecommons.org/licenses/by-nc-sa/4.0/

\section{Corresponding Author:}

Afdal, Afdal

Universitas Negeri Padang

Email: afdal@konselor.org

\section{Introduction}

The rate of dometic violence in Indonesia is high, with continuous yearly increase. Therefore, there is an adequate need for the government to implement rules to alleviate and prevent its increment. In 2017 the number of cases increased by $74 \%$ from 2016, and a massive increase of $400 \%$ in West Sumatra in 2017 , thereby, ranking this community as fifth most female violence in city (Afdal, 2015; Afdal, et.al, 2017; Komnas Perempuan, 2018).

Some factors such as lack of assertive behavior towards partners and lots more, leads to domestic violence. Some of its causes include women being quiet and submissive to their husbands, feeling inferior, no without human rights, admitting to mistakes even when they are not wrong and claiming responsibility for the actions of their partners (Anggoman \& Wirawan, 2002).

However, the wife's assertive behavior towards the partner tends to prevent domestic violence, thereby, making the relationship closer, because the higher the assertive behavior, the greater the marital satisfaction rate of the married couple and vice versa. In addition, when this behavior is raised by women, it makes the relationship better. However, it does not have an impact on those experiencing continuous violence (Wardani, Nuniek, Keliat, Budi, \& Nuraini, 2012; Kumaladewi \& Uyun, 1997; Syafira \& Kustanti, 2017).

Assertive behavior is an action used by women to express honesty, and comfort, without being anxious about their partners. It improves the quality of relationships between humans, allows them to act in the best way, express their feelings honestly and comfortably, without anxiety. Furthermore, it allows them to exercise personal rights without denial (Benjamin J. Sadock \& Virginia A. Sadock, 2005; Townsend, 2009). 
In addition, it allows them to respect better the rights, feelings, and thoughts, of their partners with the ability to communicate properly and prevent them from repeating behaviors that contain elements of emotional violence capable of hurting their feelings. Based on these results, it is concluded that assertive behavior is significant enough to influence the emotional violence experienced by women (Nugraha Dwi Aria, 2013).

It is also closely related to education, because the higher the level of education, the broader their thinking capability, therefore, it has the ability to develop people to succeed at work. Education helps people to know themselves better by determining their strengths and weaknesses, and confidence level. Formal educational experience tends to have a major impact on individual attitudes, conceptions, and ways of thinking. It helps a person to be confident that the behavioral orientation is more focused on decisions (Cahyani, 2017; Yogaryjantono, 1997).

Therefore poor education is one of the factors of domestic violence, and for this reason, this research aims to identify its differences.

\section{Method}

This is a quantitative and descriptive study on women as victims of domestic violence in Padang. Data were collected through behavioral instruments developed from Galassi theory using saturated sampling method. The research instrument was filled by 64 women using a 5 point Likert scale. RASCH model analyst results show a reliability score of (Extreme and Non-Extreme) 0.62 , while the Cronbach's alpha value (KR-20) of 0.67 , indicates that the interaction between couples is good. Besides that, the sensitivity value of the NonExtreme /INFIT MNSQis1.01 logit which is in line with the Non-Extreme/OUTFIT MNSQ, which indicates that they are still in the ideal range of $+0.5>\mathrm{MNSQ}<+1.5$ (Bond \& Fox, 2015; Boone, Stever, \& Yale, 2014; Sumintono \& Widhiarso, 2015).

Additional analysis of the RASCH modeling also found an item reliability score of 0.85 , which shows that the quality of the items used in the measurement is special. Besides that, the sensitivity value of person's answer pattern +1.01 logit (INFIT MNSQ) and +1.01 logit (OUTFIT MNSQ) as a whole, which indicates that it is still in the ideal range of $+0.5>\mathrm{MNSQ}<+1.5$. This, therefore, indicates that the items have very good quality for the conditions of the measurements made.

Furthermore, data regarding differences in assertive behavior are reviewed from an educational background using an independent sample t-test.

\section{Results and Discussions} Table 1.

Further information based on the results of the t-test on their educational background, is presented in

Table 1: Results of Independent Sample T-test

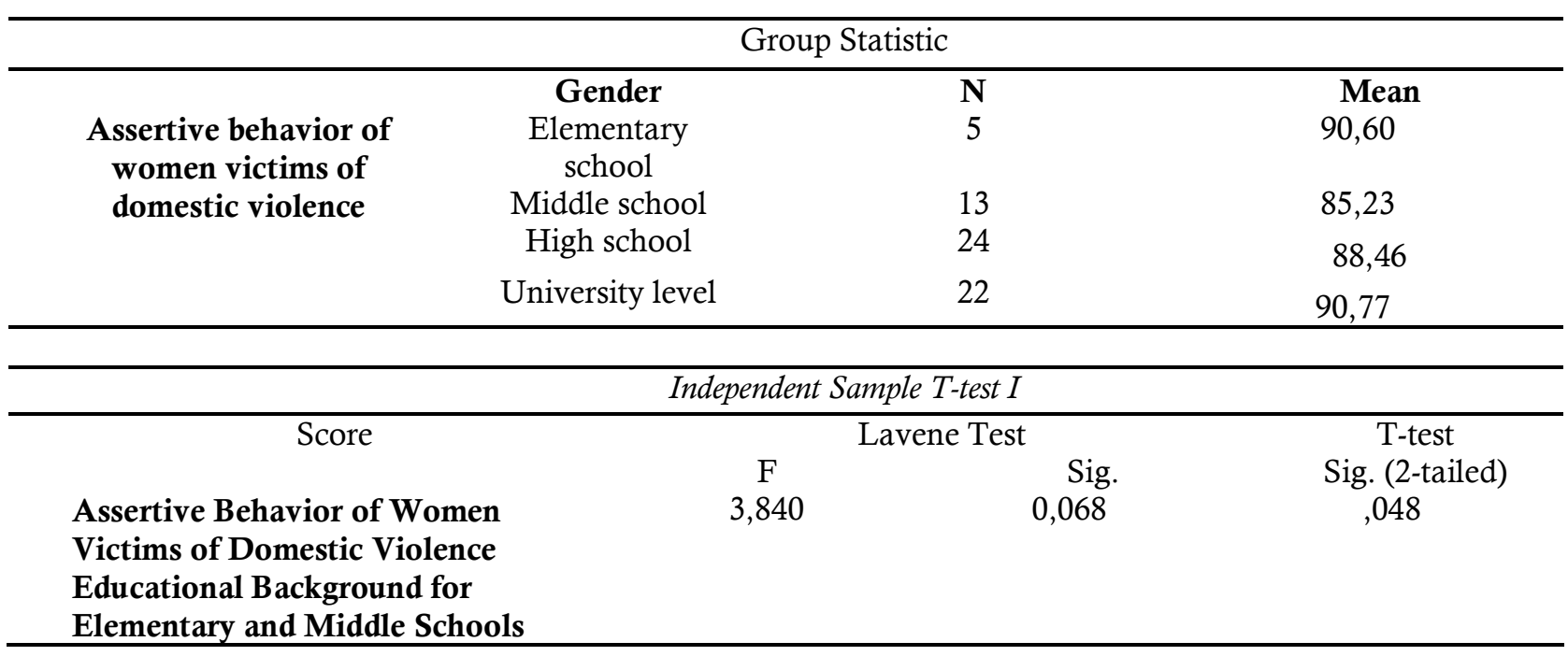




\begin{tabular}{lccc}
\hline & & & \\
\hline \multicolumn{1}{c}{ Score } & Independent Sample T-test II & \\
\hline & Lavene Test & T-test \\
& & Sig. & Sig. (2-tailed) \\
$\begin{array}{l}\text { Assertive Behavior of Women } \\
\text { Victims of Domestic Violence }\end{array}$ & 0,225 & 0,637 & 0,041 \\
$\begin{array}{l}\text { Educational Background High school } \\
\text { and university level }\end{array}$ & & & \\
\hline
\end{tabular}

In the Statistics Group table, there are 64 data on the number of women victims of domestic violence. While the mean results show the average value for each group, with an elementary education background of 90.60 , junior high school of 85.23 , high school of 88.46 , and PT of 90.77 . On the average, these values look similar, however, to determine the significant differences, the t-test is performed. In the Independent Sample T-test I, the F value of 3,840 , has a significance of 0.068 , which is greater than $0.05(0.265>0.05)$, explains that the population variance is homogeneous. Therefore, homogeneity requirements are met to test differences in assertive behavior of women based on their educational background. Furthermore, the hypothesis test with a significant value of 0.048 , indicates a p-value $>0.05$. Therefore Ho was rejected. This means that there are differences between women possessing primary and junior secondary education.

In the Independent Sample T-test II table, the F value of those with high school and PT education background is 0.225 with a significance of 0.0637 which indicates that the population variant is homogeneous at above $0.05(0.265>0.05)$. Therefore, homogeneity requirements are met to test the differences in assertive behavior based on their educational background. Furthermore, the hypothesis test shows a significant value of 0.041 and p-value $>0.05$, thereby, rejecting Ho. This means that there are differences in the assertive behavior of women with high school educational background and PT as presented in Table 2.

Table 2: Conditions of Assertive Behavior of Women Victims of Domestic Violence Against Primary Education

\begin{tabular}{lccc}
\hline \multicolumn{1}{c}{ Category } & Score Interval & f & \% \\
\hline Very high & $\geq 116$ & 0 & 0 \\
High & $94-115$ & 0 & 0 \\
Moderate & $72-93$ & 2 & 40 \\
Low & $50-71$ & 3 & 60 \\
Very low & $\leq 49$ & 0 & 0 \\
\hline
\end{tabular}

In table 2 above, the assertive behavior of women with elementary education background is in the low category (60\%). Furthermore, those with junior high school education are presented in Table 3.

Table 3: Assertive Behavior Conditions of Women Victims of Domestic Violence with Middle School Education

\begin{tabular}{lccc}
\hline \multicolumn{1}{c}{ Category } & Score Interval & f & \% \\
\hline Very high & $\geq 116$ & 0 & 0 \\
High & $94-115$ & 4 & 30,76 \\
Moderate & $72-93$ & 9 & 69,23 \\
Low & $50-71$ & 0 & 0 \\
Very low & $\leq 49$ & 0 & 0 \\
\hline
\end{tabular}

Table 3 above shows that in general those with junior high school background are in the moderate category of $69.23 \%$. Furthermore, table 4 presents those with high school education background. 
Table 4: Conditions of Assertive Behavior of Women Victims of Domestic Violence with High School Education Background

\begin{tabular}{lccc}
\hline \multicolumn{1}{c}{ Category } & Score Interval & f & \% \\
\hline Very high & $\geq 116$ & 0 & 0 \\
High & $94-115$ & 9 & 37,5 \\
Moderate & $72-93$ & 14 & 58,33 \\
Low & $50-71$ & 1 & 4,16 \\
Very low & $\leq 49$ & 0 & 0 \\
\hline
\end{tabular}

Table 4 shows that in general women with high school education background are in the moderate category of $58.33 \%$. Furthermore, the conditions of those with PT education are presented in Table 5.

Table 5: Conditions of Assertive Behavior of Women Victims of Domestic Violence with Higher Education

\begin{tabular}{lccc}
\hline \multicolumn{1}{c}{ Category } & Score Interval & f & \% \\
\hline Very high & $\geq 116$ & 0 & 0 \\
High & $94-115$ & 8 & 36,36 \\
Moderate & $72-93$ & 14 & 63,63 \\
Low & $50-71$ & 0 & 0 \\
Very low & $\leq 49$ & 0 & 0 \\
\hline
\end{tabular}
$(63.63 \%)$

Table 5 shows the assertive behavior of those with educational background in the medium category

Based on the results, women with elementary education background are more violent than those with junior, high school, and PT. This is because the higher the level of one's education the greater the tendency to succeed at work, with a better understanding of their strengths and weaknesses (Cahyani, 2017)

Formal education tends to possess a major impact on attitudes, conceptions, and people's thinking mentality. In acting, being more flexible is more open to renewal, with a broader memory and feelings capable of making someone confident that behavioral orientation is focused on the decision. Therefore, strengthened by the results of the study, people with good self-confidence are able to behave assertively. Besides that, it is also supported by Firth and Snyder umut factors, which stated that the level of education influences the development of assertiveness (Yogaryjantono, 1997).

Women with low education tend to have low assertive behavior compared to those with higher education. The educated ones have a place to obtain solutions in order to overcome the existing pressure, while those without tertiary education possess low self-esteem and are unable to determine the best remedy to their problem (Lovihan \& Kaunang, 2010).

According to Pratiwi, educated women have high self-esteem, which acts as a sense of value that comes from thoughts, feelings, sensations, and experiences collected throughout life. In addition, they behave assertively when confronted with something harmful (Pratiwi, 2015).

Women with low education are not assertive because education plays a role in the formation of an individual's behavior. This is possible because when one enters primary school, they gain a number of important knowledge regarding the social world, with guidance to determine abstract consideration and the basic principles of communication when in secondary school. Therefore, the more a person learns, the greater their knowledge, experience, understanding, behavior, acts, and thinks (Dini, Psikologi, \& Soegijapranata, 2007).

\section{Conclusions}

From the results of the study it was found that the assertive behavior of women victims of domestic violence with elementary education background was lower compared to those with junior, high school and 
PT. This is due to the fact that education plays a role in the formation of individual assertive behavior. When individuals are admitted into the primary school, they gain a number of important knowledge about their social world, and in secondary school they are guided to determine more abstract considerations which are the basic principles of human communication.

\section{References}

Afdal, A. (2015). Pemanfaatan Konseling Keluarga Eksperensial untuk Penyelesaian Kasus Kekerasan dalam Rumah Tangga. Jurnal EDUCATIO: Jurnal Pendidikan Indonesia, 1(1).

Afdal, A. (2015). Kolaboratif: Kerangka kerja konselor masa depan. Jurnal Konseling dan Pendidikan, 3(2), 1-7.

Afdal, A., Alizamar, A., Ifdil, I., Erlamsyah, E., \& Taufik, T. (2017, September). Guidance And Counseling Services For Women Victims Of Domestic Violence. In 9th International Conference for Science Educators and Teachers (ICSET 2017). Atlantis Press.

Anggoman, Y., \& Wirawan, H. . (2002). Dampak Psikologis Kekerasan Fisik di Dalam Rumah Tangga. Jurnal Ilmiah Psikologi "ARKHE, ”7(2), 91 - 99.

Benjamin J. Sadock, M. ., \& Virginia A. Sadock, M. . (2005). Kaplan and Sadock's Comprehensive Textbook Of Psychiatry (Lippincott). Philadelpia.

Bond, T. G., \& Fox, C. M. (2015). Applying the Rasch Model, Fundamentals Measurement in the Human Science (3rd edition). New York: Routledge.

Boone, W. J., Stever, J. R., \& Yale, M. S. (2014). Rasch Analysis in the Human Science. Dordrech: Springer.

Cahyani, S. D. (2017). Hubungan Harga Diri (Self Esteem) dengan Perilaku Asertif Peserta Didik SMK Negeri 3 Metro Tahun Pelajaran 2016/2017. Seminar Nasional Pendidikan 2017, 339-344.

Dini, A. B., Psikologi, F., \& Soegijapranata, U. K. (2007). Perilaku asertif orang jawa ditinjau dari tingkat pendidikan dan pola asuh demokratis orangtua.

Komnas Perempuan. (2018). Tergerusnya Ruang Aman Perempuan Dalam Politik Populisme: Catatan Kekerasan Terhadap Perempuan tahun 2017. 1-108.

Kumaladewi, V., \& Uyun, Q. (1997). 1 Naskah Publikasi Hubungan Antara Perilaku Asertif Dengan Kepuasan Perkawinan Pada Pasangan Suami Istri. 000, 1-30.

Lovihan, M. A. K., \& Kaunang, R. O. W. (2010). Perbedaan Perilaku Asertif pada Wanita Karir yang sudah Menikah dengan yang Belum Menikah. INOVASI, 7(4), 240-250.

Nugraha Dwi Aria, A. (2013). Hubungan Antara Asertivitas dengan Kekerasan Emosional yang dialami Perempuan dalam Berpacaran. Universitas Katolik Soegijapranata.

Pratiwi, W. E. K. A. (2015). Pengaruh Budaya Jawa dan Harga Diri Terhadap Asertivitas pada Remaja Siswa Kelas XDI SMA Negeri 3 Ponogoro. Jurnal Psikologi, 3(1), 348-357.

Sumintono, B., \& Widhiarso, W. (2015). Aplikasi Pemodelan Rasch pada Assessment Pendidikan. Bandung: Trim Komunikata.

Syafira, G. A., \& Kustanti, E. R. (2017). Mengalami Kekerasan Dalam Pacaran. 6(1), 186-198.

Townsend, M. C. (2009). Psychiatric Mental Health Nursing (F.A Davis). Philadelpia.

Wardani, Nuniek, S., Keliat, Budi, A., \& Nuraini, T. (2012). Peningkatan kemampuan asertif dan penurunan persepsi melalui Assertive Training Therapy. Jurnal Keperawatan Indonesia, 15(1), 61-66.

Yogaryjantono. (1997). Asertivitas Antara Perawat Ruang VIP dan Perawat Ruang Bangsal di Rumah Sakit Panti Rapih Yogyakarta. 